\title{
LONG ISLAND, PAPUA NEW GUINEA: INTRODUCTION
}

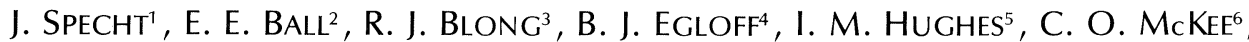 \\ AND C. F. PAIN? \\ 1. The Australian Museum, Sydney. \\ 2. Department of Neurobiology, Research School of Biological Sciences, Australian National University, \\ Canberra. \\ 3. School of Earth Sciences, Macquarie University, Sydney. \\ 4. The Australian Museum, Sydney. \\ 5. Human Studies Programme, School of General Studies, Australian National University, Canberra. \\ 6. Volcanological Observatory, Rabaul, Papua New Guinea. \\ 7. School of Geography, University of New South Wales, Sydney.
}

\section{DEDICATION}

This series of papers is dedicated to the memory of R. J. S. Cooke, who was killed by a volcanic eruption on Karkar Island on 8 March, 1979. Professionally, Rob Cooke was a volcanologist, but even more impressive than his excellent work on volcanoes was the depth and breadth of his interest in Papua New Guinea, for he was also an expert on New Guinea birds and on New Guinea history. His helpfulness and his critical abilities will be sorely missed by all of us who had the pleasure of working with him.

\section{SUMMARY}

Long Island, in the Madang Province of Papua New Guinea, forms part of the Bismarck Volcanic Arc. Most life on the island was apparently destroyed in a catastrophic eruption during the 17th or early 18th century, and the island has subsequently been recolonized by plants, animals and humans. The human population of the island is still small enough to make possible significant studies of the relation between the expanding human population and the environment. In addition, creation in 1968 of a volcanic island in the large freshwater lake filling the central caldera of the island has allowed observation of a colonization process essentially from the start. Between 1969 and 1978 the authors were engaged on research into various aspects of the island's eruptive and human history. This paper provides a general introduction to these studies which are more fully described in the following papers.

Long Island, known as Pono to its inhabitants and as Arop or Ahrup to people on the New Guinea mainland, lies about $130 \mathrm{~km}$ east of Madang and $65 \mathrm{~km}$ north-east from Saidor in the Madang Province of Papua New Guinea (Fig. 1). The island is part of the Bismarck Volcanic Arc, a series of Quaternary volcanic centres running from the Schouten Islands in the west to Rabaul on New Britain in the east. Some 900 people speaking an Austronesian language inhabit the island, most of them in the five main settlements of Bok, Kaut, Malala, Poin Kiau and Matapun.

The island was given its English name by Dampier, who sailed past it in AD 1700. However, it is roughly hexagonal in plan, with a maximum width of about $30 \mathrm{~km}$ and a land area of about $328 \mathrm{~km}^{2}$ (Fig. 2). It has a central caldera lake, Lake Wisdom, (area $86^{*} \mathrm{~km}^{2}$ ) at each end of which an extinct volcanic cone rises over 1,000 metres. The island has a variety of habitats which reflect the altitudinal range (Figs. 3-6).

*This figure has been given elsewhere (e.g. Ball \& Glucksman 1978) as $95 \mathrm{~km}^{2}$ based on the 1:63360 U.S. Army Papua New Guinea 1:100,000 Topographic Survey Sheet 8387 (1977) the figure should be $86 \mathrm{~km}^{2}$. 